\title{
Relationship of sociodemographic and lifestyle factors and diet habits with metabolic syndrome (MetS) in a multi-ethnic Asian population
}

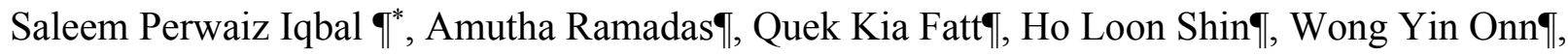
Khalid Abdul Kadir 9

\Ueffrey Cheah School of Medicine and Health Sciences, Monash University, Malaysia

Short title: Sociodemographic \& lifestyle factors and diet habits in MetS

*Corresponding author:

Saleem Perwaiz Iqbal

Jeffrey Cheah School of Medicine and Health Sciences

Monash University,

Malaysia

Email: saleem.iqbal@monash.edu 


\section{Abstract}

\section{Objectives}

Literature shows a high prevalence of MetS among Malaysians, varying across major ethnicities. As sociodemographic characteristics, lifestyle factors and diet habits of such communities have been reported to be diverse, the study objective was to investigate the association of various sociodemographic characteristics, lifestyle factors and diet habits on MetS overall and among the three major ethnic communities in Malaysia.

\section{Materials and Methods}

We conducted a cross-sectional study among 481 Malaysians of age 18 years and above living in Johor, Malaysia. Information on demographics, lifestyle and diet habits was collected using a structured questionnaire. MetS was diagnosed among the subjects using the Harmonized criteria. Multiple logistic regression was used to analyse associations between sociodemographic and lifestyle factors and dietary behaviours with MetS.

\section{Results}

MetS was found among $32.2 \%$ of the respondents, more prevalent among the Indians (51.9\%), followed by Malays (36.7\%) and Chinese (20.2\%). Overall, increasing age ( $\mathrm{AOR}=2.44[95 \% \mathrm{CI}=1.27-4.70]$ at $40-49$ years vs. $\mathrm{AOR}=4.14[95 \% \mathrm{CI}=1.97-8.69]$ at 60 years and above) and Indian ethnicity $(\mathrm{AOR}=1.95[95 \% \mathrm{CI}=1.12-3.38)]$ increased, while higher education $(\mathrm{AOR}=0.44[95 \% \mathrm{CI}=0.20-0.94]$ reduced the odds of MetS in this population. Quick finishing of meals $(\mathrm{AOR}=2.17[95 \% \mathrm{CI}=1.02-4.60])$ and low physical activity $(\mathrm{AOR}=4.76[95 \% \mathrm{CI}=1.49-15.26])$ was associated with an increased odds of MetS among the Malays and Chinese, respectively. 


\section{Conclusion}

The population in Johor is diverse in these factors, and some of these are associated with MetS in certain ethnicities. In light of such differences, ethnic specific measures are needed to reduce the prevalence of MetS in this population.

\section{Keywords}

Metabolic syndrome, Ethnicity, Prevalence, Lifestyle, Diet habits, Physical activity, Malaysian population 


\section{Introduction}

Metabolic syndrome (MetS) is a combination of interrelated risk factors that predisposes individuals to the development of cardiovascular disease (CVD) and diabetes. This includes hyperglycemia, raised blood pressure, hypertriglyceridemia, low high-density lipoprotein (HDL)cholesterol levels, and abdominal obesity, and is now recognized as a disease by the World Health Organization (WHO) and other international entities $(1,2)$.

According to a research across 7 European countries, the overall prevalence of MetS was estimated to be $23 \%$ using the WHO criteria (3). In Canada, nearly $25 \%$ of the adult population was found to be afflicted with MetS using the National Cholesterol Education Program (NCEP) - Adult Treatment Panel III (ATP III) (4). In Australia, the prevalence values of MetS using the WHO, NCEP-ATP III and International Diabetes Federation (IDF) criteria were $21.7 \%$, 21.1\% and $30.7 \%$, respectively $(5,6)$. This points to the fact that prevalence of MetS within the same region may vary as different definitions are employed; and this could be due to the differences in the defined cut offs for its associated metabolic risk factors.

As the proportion and distribution of body fat in Asians, in general, were found to be different from Caucasians in North America and Europe, it became apparent that the definition of obesity applied to Western populations would not be applicable to Asian populations $(7,8)$. Therefore, the estimated prevalence values of MetS among Asians were found to be increased when Asianadapted definitions of obesity were employed in the NCEP-ATP III. For example, in the Southeast Asian region, it increased from $13.1 \%$ to $20.9 \%$ for Singaporean males and for the Chinese adults, it increased from $10.1 \%$ to $26.3 \%(9,10)$. A similar trend was observed among the Malaysians where during the 2008 nationwide survey an overall prevalence of $42.5 \%$ from 4341 subjects was reported using the Joint Interim Statement (JIS) "Harmonized" criteria, compared to $34.3 \%$ via the 
NCEP-ATP III criteria (11). Like in NCEP-ATP III, MetS according to the Harmonized definition includes any 3 of the 5 metabolic abnormalities - central obesity, hypertriglyceridemia, low HDLcholesterol, high blood pressure and hyperglycemia (2). However, the Harmonized criteria have defined Asian cut-offs for central obesity (waist circumference: $\geq 90 \mathrm{~cm}$ for males; $\geq 80 \mathrm{~cm}$ for females) and reduced cut-off for hyperglycemia $(\geq 5.6 \mathrm{mmol} / \mathrm{L}$, instead of $6.1 \mathrm{mmol} / \mathrm{L}$ in the NCEP-ATP III). Ramli et al., using the Harmonized definition reported the prevalence of MetS to be $43.4 \%$ in 2013, from among 8,836 subjects across East and West Malaysia (12). This percentage was very close to the $42.5 \%$ prevalence reported in the 2008 nationwide survey (11).

The prevalence of MetS is dependent on a variety of non-modifiable (gender, age, ethnicity) and modifiable (lifestyle, diet) risk factors. These factors are known to, directly or indirectly, influence MetS among populations. For instance, Wen and colleagues reported the prevalence of Mets in rural China as 44.3\% (by modified NCEP-ATP III criteria), 40.7\% (by IDF criteria) and 47.7\% (by Harmonized criteria), amongst a large cohort of 4748 subjects, primarily among females aged 50 years and above (13). From a study in Canada, Liu and colleagues reported MetS prevalence to be higher among Cree Indians compared to other aboriginal and non-aboriginal Canadians (14). Malaysia is no different as according to the nationwide survey the prevalence was found to be higher among older age groups, more among females, and most common among the Indians compared to other races in Malaysia (11).

Studies have shown that various lifestyle factors influence MetS. Sedentary lifestyle and physical inactivity have been shown to contribute to the development of MetS and its components (15-19). Smoking and alcohol consumption have also shown to have variable influences on MetS and its components (20-24). Furthermore, diet habits such as speed of eating, dining out, skipping breakfast and late dinners have been found to be associated with increased incidence of MetS (25, 
26). These factors are present in most communities and might provide some insight on how their influence on MetS may be regulated in populations to contain its life-threatening complications. Reports mentioned above indicate the important influence of lifestyle habits on prevalence of MetS in a particular population. Malaysia is a unique country in Southeast Asia because of its ethnic diversity, culture, lifestyle choices and dietary intake habits. The influence of differing lifestyle choices and diet habits across the 3 major races of the country may provide a better understanding of the high prevalence of MetS in the country, along with measures for its containment. There have been only a few studies carried out in Malaysia on investigating the influence of lifestyle factors with the risk of MetS among the Malaysian population (27-29). While the two studies by Chu and Moy described the influence of physical activity on MetS on the Malays, the only study which dealt with ethnic differences with respect to physical activity and prevalence of MetS among the Malaysian population was based on the data that were collected more than 13 years ago (27-29). Moreover, in that study the relationship of lifestyle behaviours with MetS among major ethnicities was not reported (29). Therefore, the objective of the present study, therefore was to determine the association of sociodemographic characteristics, lifestyle factors and diet habits with the risk of MetS, overall and among the 3 major ethnic groups residing in Johor, Malaysia. 


\section{Materials and methods}

\section{Study design and location}

This was a cross-sectional study, employing a nonprobability sampling strategy, conducted in Kulai and Felda Taib Andak of the Kulai district and Johor Bahru, Ulu Tiram and Kota Masai of the Johor Bahru district of Malaysia.

\section{Recruitment and eligibility criteria}

Research camps were set up in central locations of Kulai and Johor Bahru districts, which were easily accessible to the target community. The selection of these study locations was partly based on the available percentages of MetS across each major ethnicity of Malaysia, reported in the nationwide survey 2008 , to have enough subjects to represent each ethnicity in Johor so that data could be available for in-depth analysis for the stated objectives. Assistance was sought from community elders for making the locals aware of research camps and to convey the requests for their participation.

The inclusion criteria for the study were that the subjects should be of age 18 years or above, of either sex, and had been residing in Johor for at least one year. The subjects were requested to observe a 10 to 12-hour fast before arriving at the medical camp to donate blood samples for accurate assessment of fasting serum levels of glucose, triglycerides and HDL-cholesterol. Exclusion criteria included pregnancy or having any illness which could preclude their participation in the study such as cancer, liver disease, etc. Consented participants were invited to visit these camps for a physical examination and collection of blood samples upon observing a 10 to 12-hour fast. Upon sample collection, the subjects were asked about their lifestyle and dietary habits. Participants not observing the 10-12 hour fast were excluded from the analysis. 


\section{Data collection and measurement}

Data from the participants were collected using a structured questionnaire and proforma which contained information on anthropometric measurements, measurement of blood pressure, blood sample analysis results and questions on sociodemographic and lifestyle behaviors. The questionnaire was designed in English and back translated in the Bahasa Malaysia language. In the study, Bahasa language based version was used.

Body height was measured using Seca stadiometers (Seca, USA), while the weight was measured using the InBody 120 body fat analyzer (Biospace, Korea). Measures were taken to ensure that the subjects wore light clothing and no shoes. The measurement was recorded to the nearest $0.1 \mathrm{~cm}$ and $0.1 \mathrm{~kg}$, respectively.

Waist circumference was measured using a measuring tape. The measurements were taken at the mid-point, between the lower rib margin $\left(12^{\text {th }}\right.$ rib) and the iliac crest. Caution was maintained during measurements that the subject was standing straight with feet together and arms relaxed on either side. It was also ensured that the tape was held in a horizontal position, wrapped around the waist, loose enough for the assessor to insert his/her finger between the tape and the subject's body. The subject was instructed to breathe normally during the assessment, with the measurement recorded at the end of a normal exhalation and rounded to the nearest $0.1 \mathrm{~cm}$.

Blood pressure was recorded using the Omron digital sphygmomanometers (HEM-7121, Omron Healthcare, Japan). The subject was provided a 4-5 minute rest, in a seated position, with the arm supported at heart level. At least two readings were taken from each subject, recording the concurrent or highest measurement obtained from the two readings. A third reading was taken in case, the difference between the two readings for systolic blood pressure was more than $10 \mathrm{mmHg}$, and for diastolic blood pressure more than $5 \mathrm{mmHg}$. 
Fasting blood samples were collected from study participants for determining the levels of fasting serum glucose (in mmol/L), fasting serum triglycerides (in mmol/L) and fasting serum HDLcholesterol (in mmol/L). Standard guidelines for phlebotomy were followed throughout the venipuncture procedure (30).

Collected samples were transported in cold chain to the laboratory where these were centrifuged, and the sera samples were separated and placed in identity marked cryotubes or Eppendorf tubes. These were then placed in a -60 degree Celsius freezer till laboratory analysis.

The blood analysis for determination of serum levels of fasting glucose (mmol/L), triglycerides (mmol/L) and HDL-cholesterol (mmol/L) was carried out using clinical chemistry analyser (Cobas C III). Its reagents were purchased from Randox Laboratories, United Kingdom.

The participants' physical activity status was inquired using the International Physical Activity Questionnaire (IPAQ) (31). The questionnaire contained seven questions; the first two pertaining to the time spent on vigorous activities performed, the next two for moderate activities, the next two for mild activities and the last question was on the time spent while sitting. Responses were converted to Metabolic Equivalent Task minutes per week (MET-min/week) according to the IPAQ scoring protocol. The protocol also provides details for data processing, cleaning and truncation. Total minutes over last seven days spent on vigorous, moderate, and mild activities were multiplied by 8.0, 4.0, and 3.3, respectively, to create MET scores for each activity level. MET scores across the three sub-components were then summed to indicate the overall physical activity score. These overall scores were then categorized into high (total activity of at least 3000 MET-min/week), moderate (total activity of at least $600 \mathrm{MET}-\mathrm{min} /$ week) and low (total activity < $600 \mathrm{MET}-\mathrm{min} /$ week). 
Diet habits included quick finishing of their meals, frequency of late dining, frequency of skipping breakfast and frequency of dining out. For quick finishing of meals, the question was asked on the subject's perception on finishing their meals either fast (less than 10-15 minutes) or not fast (3234). The assessment of the other three diet habit questions (frequency of late dining, frequency of skipping breakfast and frequency of dining out) were based on the participants' frequency per week; three times or less were considered favorable (32). "Late dining" was defined as a meal eaten within two hours before bed-time. "Dining out" was defined as a meal consumed by the participant that is not prepared at his/her home (35-37).

\section{Definition of MetS}

MetS was defined using the Harmonized criteria as having at least 3 of the following 5 risk factors: 1) Abdominal obesity, defined as having a waist circumference $\geq 90 \mathrm{~cm}$ for males and $\geq 80 \mathrm{~cm}$ for females; 2) Raised serum triglycerides (hypertriglyceridemia), defined as $1.7 \mathrm{mmol} / \mathrm{L}$ (150 mg/ $\mathrm{dL})$; 3) Low high density lipoprotein cholesterol (HDL-C), defined as $1.0 \mathrm{mmol} / \mathrm{L}$ (40 mg/dL) for males and $1.3 \mathrm{mmol} / \mathrm{L}(50 \mathrm{mg} / \mathrm{dL})$ for females; 4) Raised blood pressure, defined as a systolic blood pressure $\geq 130$ or a diastolic blood pressure $\geq 85 \mathrm{mmHg}$, or current use of anti-hypertensive medications; and 5) Raised fasting blood sugar (hyperglycemia), defined as $\geq 5.6 \mathrm{mmol} / \mathrm{L}$ (100 $\mathrm{mg} / \mathrm{dL}$ ) or current use of anti-diabetic medications.

\section{Statistical analysis}

Data entry was performed using EpiData version 3.1. During the process of data entry, $5 \%$ of the forms were re-checked for accounting any errors during entry of data. All data were analyzed using Statistical Package for Social Sciences (SPSS) version 23 (IBM SPSS Statistics for Windows, Version 23.0. Armonk, NY: IBM Corp.). 
The sample size estimate was calculated using estimates of various components of MetS reported in the 2008 nationwide survey (11). According to the calculation, increased blood pressure (> $130 / 85 \mathrm{mmHg}$ ) yielded the sample size estimate of 386 at $5 \%$ level of significance and a precision of 0.05 .

Frequencies and percentages were obtained for categorical variables. Chi square tests for Independence were used to determine the univariate association between categorical variables. Multiple logistic regression analyses was used to determine the associations of sociodemographic and lifestyle factors with MetS, calculating odds ratios with $95 \%$ confidence intervals, while adjusting for confounding factors. Variables, with $\mathrm{p}<0.25$ on univariate analysis were selected for adjustment in the final logistic regression model. $\mathrm{P}<0.05$ was considered statistically significant.

\section{Ethics}

Ethical approval was sought from the Monash University Human Research Ethics Committee (Project \# CF15/56-2016000022). 


\section{Results}

The prevalence of MetS was found to be $32.2 \%$ in the study subjects, according to the Harmonized criteria; highest among the Indians (51.9\%) and lowest among the Chinese (20.2\%) (Fig 1). Abdominal obesity $(62.0 \%)$ and high blood pressure $(56.8 \%)$ were more common compared to other metabolic abnormalities. Three most prominent MetS risk factors among Malays and Indians were abdominal obesity, high blood pressure and low HDL-cholesterol. Among the Indians however, the percentages of abdominal obesity and HDL-cholesterol were higher than that among the Malays. Prevalence of high blood pressure was more prominent among the Malays compared to the other ethnic groups. Among the Chinese, the third most prevalent risk factor was hypertriglyceridemia. Prevalence of low HDL-cholesterol was at its lowest among the Chinese.

Table 1 shows the comparative association of sociodemographic and lifestyle characteristics with MetS overall, and across the 3 major ethnicities in Johor. Overall, significant differences are observed with age, ethnicity, marital status, education and physical activity $(\mathrm{p}<0.05)$. Marital status and education were found to be significantly related with MetS among the Malays, while age and physical activity among the Chinese and age among the Indians showed a significant association with MetS. Among the Malays, 59.4\% of the people with primary education or lower were having MetS, suggesting that those Malays having higher education appear to be protected against the risk of MetS $(\mathrm{p}<0.05)$. Majority of the Indians appear to be afflicted with MetS at a younger age $(41.6 \%$ at the age group of $40-49$ years; $p<0.001)$. Conversely, only $15.2 \%$ of the Chinese were suffering from this syndrome in this age group $(\mathrm{p}=0.016)$. This shows that the Chinese in Johor are getting this disease at a relatively older age.

Table 2 shows the adjusted multiple logistic regression model, the results of which indicate that overall in this population, higher age groups and the Indian race had increased the odds of having 
MetS, while the Chinese ethnicity and tertiary education were protective against the risk of MetS.

Lifetsyle factors and the diet habits did not appear to have any association with MetS, overall, in the adjusted model $(\mathrm{p}>0.05)$.

In view of the contrasting estimates of MetS among the ethnicities, we explored the effect of ethnicity further with sociodemographic, lifestyle and diet factors. Table 3 shows the adjusted logistic regression models among the Malays, the Chinese and the Indians, revealing higher odds for MetS for quick finishing of meals among the Malays $(\mathrm{AOR}=2.17[95 \% \mathrm{CI}=1.02-4.60])$ and low physical activity among the Chinese $(\mathrm{AOR}=4.76[95 \% \mathrm{CI}=1.49-15.26])$. Furthermore, higher educational categories were protective against MetS among the Malays. Among the Indians, older age groups (40 years and above) were more prone to developing MetS, while significant odds with respect to age were found among the Chinese older than 60 years of age $(\mathrm{AOR}=5.43$ $[95 \% \mathrm{CI}=1.39-21.13])$. 


\section{Discussion}

In this study, the prevalence of MetS was found to be $32.2 \%$, which was unexpectedly less than that reported in the 2008 nationwide survey, that contained 19\% of subjects from Johor (11). Prevalence among the Indians and the Chinese turned out to be $51.9 \%$ and $20.2 \%$, respectively. Comparing the prevalence values reported in the nationwide survey 2008 for these 2 ethnic groups in Malaysia, the prevalence among the Indians appears to have remained unchanged over a period of 9 years, however among the Chinese, the prevalence has reduced considerably from $42.1 \%$ to $20.2 \%$, while among the Malays the prevalence has decreased from $43.9 \%$ to $36.7 \%$ (11). This apparent decline among the Malays and the Chinese may be attributed to the decreased prevalence values of hyperglycemia, low HDL-cholesterol and hypertriglyceridemia.

The present study showed that MetS was more prominent among the higher age groups. This finding has been observed by other researchers also. He et al., reported a comparatively higher prevalence of MetS among older subjects (70 years and above) compared to those aged between 60-69 years among a total of over two thousand Chinese subjects. (38). In the study by Rampal et al., the prevalence of MetS among Malaysians was found to be higher among subjects aged 40 years and above compared to subjects less than 40 years (44.6\% vs. 16.0\%) (39). Also, in the study by Ramli and colleagues, the odds of MetS, irrespective of definition applied, were found to be higher among higher age groups, and maximum among subjects aged 60 years and above (12). The nationwide survey also reported higher prevalence of MetS among higher age groups; additionally, higher age groups also had a higher prevalence of central obesity, high blood pressure, low HDL-cholesterol, elevated triglycerides and hyperglycemia (11). This suggests that higher prevalence of MetS among higher age groups may be due to the accumulated higher prevalence of its associated cardio-metabolic risk factors among elderly subjects. 
Studies have shown that ethnicity influences (directly or indirectly) the prevalence of metabolic syndrome. For instance, from a study in Canada, MetS prevalence was reported to be higher among the Cree Indians compared to other aboriginal and non-aboriginal Canadians (14). The Cree Indians also had a higher prevalence of central obesity and hyperglycemia compared to other races in the country (14). Similarly, from a study in Suriname, South America, MetS prevalence was reported as the highest among the Hindustanis (descendent of Indians), compared to other Suriname races (40). The prevalence values of high blood pressure, low HDL-cholesterol and hyperglycemia were also high among the Suriname Hindustanis (40). In our study, results show that the Chinese appear to be less prone to developing MetS, while the Indians in Johor are at a greater risk of developing MetS. This is in line with the reports from other researchers from Malaysia that the Chinese have lower odds, while the Indians have higher odds of developing MetS $(12,39)$. More educated adults in the Johor area, especially Malays, appear to be protected against MetS, probably due to their more awareness of healthy lifestyle habits, such as physical activity, smoking cessation, moderate to none consumption of alcohol and adoption of healthy eating habits (32). This is supported by a couple of studies showing that higher education of individuals is protective against diabetes and hypertension, which are prominent risk components of MetS (41, 42). However, Ching et al., have recently reported that higher education levels of Malaysian vegetarians with and without MetS were nearly the same (43). This could be due to the fact that that was a unique group of subjects with specific dietary habits and the results pertaining to this group may not represent the general population of Malaysia.

Literature suggests that excess energy accumulated in the adipose tissues causes metabolic abnormalities, leading to high blood pressure, hyperglycemia, hypertriglyceridemia and inflammation, hence, regular physical activity enhances energy consumption leading to a reduced 
prevalence of obesity, hypertension, diabetes mellitus and also MetS $(44,45)$. Our results show the prevalence of MetS and its components to be comparatively lower among Chinese than in Malays and Indians, which may be likely attributed to better lifestyle choices, including physical activity. Chu et al., have shown that longer sitting time and insufficient physical activity have resulted in an almost 4-fold increase in MetS risk among the Malays, and the risk gets reduced by $50 \%$ by engaging in moderate to high physical activity $(27,28)$. On the basis of these reports, it can be suggested that the Chinese in Johor, though having a decreased risk of developing MetS, can still benefit by engaging in moderate to high levels of physical activity.

Although a number of studies have shown a direct relationship of smoking with the risk of MetS, yet in the current study smoking does not appear to be associated with the risk of MetS (20). This could be due to a small proportion of past and current smokers (12.9\%) in this cohort. Similarly, no association was found between alcohol consumption and risk of MetS in this population. Again the reason could be the small proportion of subjects who reported as alcohol consumers $(8.5 \%)$. The association of dietary habits, such as quick finishing of meals, frequent dining out, late eating, skipping breakfast, with MetS has been reported in other studies in the East Asian region (25, 26, 46-49). For example, Shin et al., reported faster eating as one of the risk factors for MetS among the Koreans (49). Among these dietary habits, quick finishing of meals was identified in the current study as a new risk factor for MetS in Malaysia, especially among the Malays. According to Dallman and colleagues, fast eaters may consume more food than usual, or be eating under psychological stress which affects hormones regulating metabolism (50). The underlying mechanism of such habit(s) with the metabolic health functioning, however remains unclear (49). Certain limitations warrant consideration. First, the present research study was cross-sectional in nature, assessing the exposures and outcomes at the same point in time. In this regard, the findings 
cannot indicate causality. Second, the selection of study locations harboring subjects was nonrandom and partly based on the available information on the percentage of MetS across each Malaysian ethnicity in Johor reported in the nationwide survey 2008 (11). Where this was done to have sufficient numbers of subjects in each ethnic group for better analysis and interpretation, however, a selection bias cannot be completely discounted. Furthermore, as the information collected was based on recall, hence misreporting of information cannot be completely ruled out, and this might have added some variability in our results. The variable effects are more likely attributed to the cultural diversities across the different ethnicities of Malaysia. Despite these sources of potential variability, the results provide evidence towards the association of certain sociodemographic, lifestyle and diet factors that affect the disease spectrum of MetS in Johor and with a reasonable sample size, it did provide an opportunity to have an in-depth analysis of sociodemographic and lifestyle factors and diet habits influencing MetS across the three major races of this state in the country. In this regard, we believe the research to be adequate and its findings comparable to similar studies by other investigators using a non-randomized design exploring associations of various risk factors influencing metabolic diseases within Malaysia and abroad.

Population in Johor is diverse in its habits pertaining to lifestyle and diet. Some of these factors are associated with the risk of MetS in certain ethnic groups, and modifying these factors would be important for reducing cardiovascular and metabolic health risks in the country. Malaysia is a multi-ethnic country, and it would be important to consider the ethnic variation, especially with respect to lifestyle and diet factors, hence, intervention programs would require to be tailored across the different races of the country for addressing behavior modifications. Increasing awareness among the masses through electronic and print media about the beneficial effects of 
healthy lifestyle is likely to be a very powerful approach to combat the menace of this syndrome in this country. Moreover, further prospective studies delineating the association of various diet habits among different racial communities are needed to contain the unfavorable effects of this syndrome on the overall health of Malaysians. 


\section{Acknowledgements}

Financial assistance was provided by the Clinical Research Center, Monash University, Malaysia, and by the grant awarded to Dr Amutha Ramadas by the Malaysian Ministry of Higher Education's Fundamental Research Grant Scheme (FRGS/2/2013/SKK07/MUSM/03/1). Also, the authors wish to thank Gribbles Laboratories (MS ISO 15189), Malaysia, for assisting with the laboratory assessments on the collected blood samples. We also appreciate all the assistance from Government contacts (Majlis Perbandaran Kulai) and all local community leaders. We would also like to extend our gratitude to the Monash University faculty and staff, namely Mr Chui Chor Sin, Mrs Savithri Gopal, Ms Pang Pei Ling, Ms Ungku Zulaikha Ungku Omar, Mr Muhammad Daniel Mahadzir, Dr Nor Azim and Dr Iekhsan Othman for all their support and assistance in this study. 
bioRxiv preprint doi: https://doi.org/10.1101/796144; this version posted October 7, 2019. The copyright holder for this preprint (which was not certified by peer review) is the author/funder, who has granted bioRxiv a license to display the preprint in perpetuity. It is made available under aCC-BY 4.0 International license.

\section{Conflict of interest}

The authors have no conflicts of interest to declare. 
bioRxiv preprint doi: https://doi.org/101101/796144; this version posted October 7, 2019. The copyright holder for this preprint (which was not certified by peer review) is the author/funder, who has granted bioRxiv a license to display the preprint in perpetuity. It is made available under aCC-BY 4.0 International license.

\section{Authors' contributions}

Study conceptualization: SPI, AR, QKF and KAK.

Population health screening: HLS and WYO

Project administration: SPI, AR, HLS, WYO and KAK

Data analysis and interpretation: SPI and KAK.

Manuscript writing and review: SPI, AR, QKF and KAK. 


\section{References}

1. Prajapati C, Majmudar F. Diabetes mellitus, obesity, hypertension: risk factors for metabolic syndrome. World Journal of Pharmacy and Pharmaceutical Sciences. 2014; 3(2):24532466.

2. Alberti KG, Eckel RH, Grundy SM, Zimment PZ, Cleeman JI, Donato KA et al. Harmonizing the metabolic syndrome: a Joint interim statement of the International Diabetes Federation Task Force on Epidemiology and Prevention; National Heart, Lung, and Blood Institute; American Heart Association for the Study of Obesity. Circulation. 2009; 120(16):16401645.

3. Balkau B, Charles MA, Drivsholm T, Wareham N, Yudkin JS, Morris R, Zavaroni I van Dam R, Feskens E, Gabriel R, Diet M, Nisson P, Hedblad B. Frequency of the WHO metabolic syndrome in European cohorts, and an alternative definition of an insulin resistance syndrome. Diabetes Metab. 2002; 28:364-376.

4. Anand SS, Yi Q, Gerstein H, Lonn E, Jacobs R, Vuksan V, teo K, Davis B, Montague P, Yusuf S. Study of Health Assessment and Risk in Ethnic Groups, Study of Health Assessment and Risk Evaluation in Aboriginal Peoples Investigators. Relationship of metabolic syndrome and fibrinolytic dysfunction to cardiovascular disease. Circulation. 2003;108:420-425.

5. The IDF consensus worldwide definition of the metabolic syndrome. International Diabetes Federation (IDF). 2005.

6. Cameron AJ, Magliano DJ, Zimmet PZ, Welborn T, Shaw JE. The metabolic syndrome in Australia: Prevalence using four definitions. Diabetes Res Clin Pract. 2007; 77(3):471-478.

7. WHO expert consultation. Appropriate body-mass index for Asian populations and its implications for policy and intervention strategies. Lancet. 2004;363:157-63. 
8. Deurenberg P, Deurenberg-Yap M, Guricci S. Asians are different from Caucasians and from each other in their body mass index/body fat percent relationship. Obes Rev. 2002;3(3):141146.

9. Tan CE, Ma S, Wai D, Chew SK, Tai ES. Can we apply the National Cholesterol Education Program Adult Treatment Panel definition of the metabolic syndrome to Asians? Diabetes Care. $2004 ; 27: 1182-1186$.

10. Dou XF, Zhang HY, Sun K, Wang DW, Liao YH, Ma AQ, Zhu ZM, Zhao BR, Zhao JZ, Hui RT. Metabolic syndrome strongly linked to stroke in Chinese. Zhonghua Yi Xuc Za Zhi. $2004 ; 84: 539-542$.

11. Mohamud WN, Ismail AA, Sharifuddin A, Ismail IS, Musa KI, Kadir KA, et al. Prevalence of metabolic syndrome and its risk factors in adult Malaysians: results of a nationwide survey. Diabetes Res Clin Pract. 2011;91(2):239-245.

12. Ramli AS, Daher AM, Nor-Ashikin MNK, Mat-Nasir N, Ng KK, Miskan M, Ambigga KS, Abdul Hamid H, Abd-Majid F, Abu-Bakar N, Nawawi H, Youoff K, JIS definition identifies more Malaysian adults with metabolic syndrome compared to NCEP-ATP III and IDF criteria. BioMed Research International. 2013; ID 760963. [http.//dx.doi.org/10.1155/2013/760963].

13. Wen J, Yang J, Shi Y, et al. Comparisons of different metabolic syndrome definitions and associations with coronary heart disease, stroke, and peripheral arterial disease in a rural Chinese population. PloS one. 2015;10(5):e0126832.

14. Liu J, Hanley AJ, Young TK, et al. Characteristics and prevalence of the metabolic syndrome among three ethnic groups in Canada. Int J Obes (Lond) 2006;30:669-76. 
15. Bianchi G, Rossi V, Muscari A, Magalotti D, Zoli M. Pianoro Study Group. Physical activity is negatively associated with the metabolic syndrome in the elderly. QJM. 2008;101:713721.

16. Laaksonen DE, Lakka HM, Salonen JT, Niskanen LK, Rauramaa R, Lakka TA. Low levels of leisure-time physical activity and cardiorespiratory fitness predict development of the metabolic syndrome. Diabetes Care. 2002;25:1612-1618.

17. Ford ES, Kohl HW, 3rd, Mokdad AH, Ajani UA. Sedentary behavior, physical activity, and the metabolic syndrome among U.S. adults. Obes Res 2005;13:608-614.

18. Wijndaeale K, Duvigneaud N, Matton L, et al. Sedentary behavior, physical activity and a continuous metabolic syndrome risk score in adults. Eur J Clin Nutr. 2009;63:421-429.

19. Thorp AA, McNaughton SA, Owen N, Dunstan DW. Independent and joint associations of TV viewing time and snack food consumption with the metabolic syndrome and its components; a cross-sectional study in Australian adults. Int J Behav Nutr Phys Act. 2013;10.96. doi: $10.1186 / 1479-5868-10-96$.

20. Sun K, Liu J, Ning G. Active smoking and risk of metabolic syndrome: a meta-analysis of prospective studies. PLoS One. 2012;7:e47791. .

21. Schroder H, Morales-Molina JA, Bermejo S et al. Relationship of abdominal obesity with alcohol consumption at population scale. Eur J Nutr. 2007;46:369-376.

22. Whitfield JB, Heath AC, Madden PA et al. Metabolic and biochemical effects of low-tomoderate alcohol consumption. Alcohol Clin Exp Res. 2013;37:575-586.

23. Taylor B, Irving HM, Baliunas D et al. Alcohol and hypertension: gender differences in dose-response relationships determined through systematic review and meta-analysis. Addiction. 2009;104:1981-1990. 
24. Koppes LL, Dekker JM, Hendriks HF et al. Moderate alcohol consumption lowers the risk of type 2 diabetes: a meta-analysis of prospective observational studies. Diabetes Care. $2005 ; 28: 719-725$.

25. Tajima M, Lee JS, Watanabe E, Park JS, Tsuchiya R, Fukahori A, et al. Association Between Changes in 12 Lifestyle Behaviors and the Development of Metabolic Syndrome During 1 Year Among Workers in the Tokyo Metropolitan Area. Circulation Journal. 2014;78(5):1152-9. 26. Zhu B, Haruyama Y, Muto T, Yamazaki T. Association between eating speed and metabolic syndrome in a three-year population-based cohort study. J Epidemiol. 2015;25(4):3326. doi:10.2128/jea.JE20140131.

27. Chu AH, Moy FM. Association between physical activity and metabolic syndrome among Malay adults in a developing country, Malaysia. J Sci Med Sport. 2014;17(2):195-200. doi:10.1016/j.jsams.2013.04.003.

28. Chu AH, Moy FM. Joint association of sitting time and physical activity with metabolic risk factors among middle-aged Malays in a developing country: a cross-sectional study. PLoS One. 2013;8(4):e61723. doi: 10.1371/journal.pone.0061723.

29. Tan AK, Dunn RA, Yen ST. Ethnic disparities in metabolic syndrome in Malaysia: an analysis by risk factors. Metab Syndr Relat Disord 2011; 9(6): 441-51.

30. WHO Guidelines on Drawing Blood: Best Practices in Phlebotomy. Geneva: World Health Organization; 2010. Chapter 2: Best practices in phlebotomy. Available from: https://www.ncbi.nlm.nih.gov/books/NBK138665/.

31. Craig CL, Marshall AL, Sjostrom M, Bauman AE, Booth ML, Ainsworth BE, et al. International physical activity questionnaire: 12-country reliability and validity. Med. Sci. Sports Exerc. 2003;35(8):1381-95. 
32. Tajima M., Lee JS., Watanabe E, et al. Association between changes in 12 lifestyle behaviors and the development of metabolic syndrome during 1 year among workers in the Tokyo metropolitan area. Circ J. 2014;78:1152-1159.

33. Otsuka R, Tamakoshi K, Yatsuya H, Wada K, Matsushita K, Ouyang P, et al. Eating fast leads to insulin resistance: findings in middle-aged Japanese men and women. Prev Med 2008;46:154-9.

34. Maruyama K, Sato S, Ohira T, et al. The joint impact on being overweight of self reported behaviours of eating quickly and eating until full: cross sectional survey. BMJ 2008;337:a2002.

35. Keke, C.; Yana, H. Research Advancement of Association of Eating out of Home with Health. Food Nutr. China 2014, 20, 67-71.

36. Lin B.H., Guthrie J., Frazão E. American's Eating Habits: Changes and Consequences. Department of Agriculture, Economics Research Service; Washington, DC, USA: 1999. Nutrient contribution of food away from home.

37. Hu P, Huang W, Bai R, et al. Knowledge, Attitude, and Behaviors Related to Eating Out among University Students in China. Clifton P, Huxley R, eds. International Journal of Environmental Research and Public Health. 2016;13(7):696. doi:10.3390/ijerph13070696.

38. He Y, Jiang B, Wang J, et al. Prevalence of the metabolic syndrome and its relation to cardiovascular disease in an elderly Chinese population. Journal of the American College of Cardiology. 2006;47(8):1588-1594.

39. Rampal S, Mahadeva S, Guallar E, Bulgiba A, Mohamed R, Rahmat R. et al. Ethnic differences in the prevalence of metabolic syndrome: results from a multi-ethnic population-based survery in Malaysia. PLoS One. 2012;7(9):e46365. doi: 10.1371/journal.pone.0046365. 
40. Krishnadath ISK, Toelsie JR, Hofman A, et al. Ethnic disparities in the prevalence of metabolic syndrome and its risk factors in the Suriname Health Study: a cross-sectional population study. BMJ Open 2016;6:e013183. doi: 10.1136/bmjopen-2016-013183.

41. Borrell LN, Dallo FJ, White K. Education and diabetes in a racially and ethnically diverse population. Am J Public Health. 2006;96: 1637-1642. pmid:16873745

42. Yan LL, Liu K, Daviglus ML, Colangelo LA, Kiefe CI, Sidney S, et al. Education, 15-year risk factor progression, and coronary artery calcium in young adulthood and early middle age: the coronary artery risk development in young adults study. JAMA. 2006;295: 1793-1800. pmid: 16622141

43. Ching YK, Chin YS, Appukutty M, Gan WY, Ramanchadran V, Chan YM. Prevalence of Metabolic Syndrome and Its Associated Factors among Vegetarians in Malaysia. Int J Environ Res Public Health. 2018 Sep 17;15(9). pii: E2031. doi: 10.3390/ijerph15092031.

44. Despres JP, Lemieux I, Bergeron J et al. Abdominal obesity and the metabolic syndrome: contribution to global cardiometabolic risk. Arterioscler Thromb Vasc Biol. 2008;28:1039-1049. 45. Warburton DE, Nicol CW, Bredin SS. Health benefits of physical activity: the evidence. CMAJ. 2006;174:801-809.

46. Oh C, Kim HS, No JK. Impact of dining out on nutritional intake and metabolic syndrome risk factors: data from the 2011 Korean National Health and Nutrition Examination Survey. Br J Nutr. 2015;113(3):473-8. doi:10.1017/S0007114514003870.

47. Yeo R, Yoon SR, Kim OY. The Association between Food Group Consumption Patterns and Early Metabolic Syndrome Risk in Non-Diabetic Healthy People. Clin Nutr Res. 2017;6(3):172-182. 
48. Otsuka R, Tamakoshi K, Yatsuya H, Murata C, Sekiya A, Wada K, Zhang HM, Matsushita K, Sugiura K, Takefuji S, OuYang P, Nagasawa N, Kondo T, Sasaki S, Toyoshima H. Eating fast leads to obesity: findings based on self-administered questionnaires among middle-aged Japanese men and women. J Epidemiol. 2006 May;16(3):117-24.

49. Shin A, Lim SY, Sung J, Shin HR, Kim J. Dietary intake, eating habits, and metabolic syndrome in Korean men. J Am Diet Assoc. 2009 Apr;109(4):633-40. doi: 10.1016/j.jada.2008.12.015.

50. Dallman MF, Pecoraro N, Akana SF, Murata C, Sekiya A, Wada K, Zhang HM, Matsushita K, Sugiura K, Takefuji S, OuYang P, Nagasawa N, Kondo T, Sasaki S, Toyoshima H. Chronic stress and obesity: A new view of "comfort food.” Proc Natl Acad Sci U S A. 2003;100: 1169611701. 
bioRxiv preprint doi: https://doi.org/10.1101/796144; this version posted October 7,2019 . The copyright holder for this preprint (which was not certified by peer review) is the author/funder, who has granted bioRxiv a license to display the preprint in perpetuity. It is made available under aCC-BY 4.0 International license.

\section{Tables}


Table 1: Summary of sociodemographic, lifestyle and dietary characteristics with MetS, overall and among the three major ethnic groups in Johor

\begin{tabular}{|c|c|c|c|c|c|c|c|c|c|c|c|c|c|}
\hline & & \multicolumn{3}{|c|}{ Overall } & \multicolumn{3}{|c|}{ Malay } & \multicolumn{3}{|c|}{ Chinese } & \multicolumn{3}{|c|}{ Indian } \\
\hline & & $\begin{array}{c}\text { Total } \\
(n=481)\end{array}$ & $\begin{array}{c}\text { With MetS } \\
(n=155)\end{array}$ & P-value* & $\begin{array}{c}\text { Total } \\
(n=147)\end{array}$ & $\begin{array}{c}\text { With MetS } \\
(n=54)\end{array}$ & P-value* & $\begin{array}{c}\text { Total } \\
(n=228)\end{array}$ & $\begin{array}{c}\text { With MetS } \\
(n=46)\end{array}$ & P-value* & $\begin{array}{c}\text { Total } \\
(n=106)\end{array}$ & $\begin{array}{c}\text { With MetS } \\
(n=55)\end{array}$ & P-value* \\
\hline \multicolumn{2}{|c|}{ Characteristic } & n (\%) & n (\%) & & n (\%) & n (\%) & & n (\%) & n (\%) & & n (\%) & n (\%) & \\
\hline \multirow[t]{2}{*}{ Gender } & Male & $169(35.1)$ & $57(36.8)$ & 0.604 & $42(28.6)$ & $12(22.2)$ & 0.194 & $88(38.6)$ & $20(43.5)$ & 0.447 & $39(36.8)$ & $25(45.5)$ & 0.055 \\
\hline & Female & 312 (64.9) & $98(63.2)$ & & $105(71.4)$ & $42(77.8)$ & & $140(61.4)$ & $26(56.5)$ & & 67 (63.2) & $30(54.5)$ & \\
\hline \multirow[t]{4}{*}{ Age (years) } & $<40$ & $112(23.3)$ & $22(14.2)$ & 0.005 & $38(25.9)$ & $12(22.2)$ & 0.442 & $40(17.5)$ & $3(6.5)$ & 0.016 & $34(32.1)$ & 7 (12.7) & $<0.001$ \\
\hline & $40-49$ & $129(26.8)$ & $48(31.0)$ & & $56(38.1)$ & $18(33.3)$ & & 35 (15.4) & $7(15.2)$ & & $38(35.8)$ & $23(41.8)$ & \\
\hline & $50-59$ & $117(24.3)$ & $36(23.2)$ & & $32(21.8)$ & $14(25.9)$ & & $71(31.1)$ & $11(23.9)$ & & $14(13.2)$ & $11(20.0)$ & \\
\hline & $\geq 60$ & $123(25.6)$ & 49 (31.6) & & $21(14.3)$ & $10(18.5)$ & & $82(36.0)$ & $25(54.3)$ & & 20 (18.9) & $14(25.5)$ & \\
\hline \multirow[t]{3}{*}{ Ethnicity } & Malay & $147(30.6)$ & $54(34.8)$ & $<0.001$ & - & - & - & - & - & - & - & - & - \\
\hline & Chinese & $228(47.4)$ & $46(29.7)$ & & - & - & & - & - & & - & - & \\
\hline & Indian & $106(22.0)$ & $55(35.5)$ & & - & - & & - & - & & - & - & \\
\hline \multirow[t]{3}{*}{ Marital status } & Single & $63(13.1)$ & $13(8.4)$ & 0.002 & $5(3.4)$ & $3(5.6)$ & 0.035 & 49 (21.5) & $7(15.2)$ & 0.284 & $9(8.5)$ & $3(5.5)$ & 0.420 \\
\hline & Married/living with partner & $378(78.6)$ & $123(79.4)$ & & $126(85.7)$ & $41(75.9)$ & & $168(73.7)$ & $38(82.6)$ & & $84(79.2)$ & $44(80.0)$ & \\
\hline & Separated/divorced & $40(8.3)$ & $19(12.3)$ & & $16(10.9)$ & $10(18.5)$ & & $11(4.8)$ & $1(2.2)$ & & $13(12.3)$ & $8(14.5)$ & \\
\hline \multirow[t]{3}{*}{ Education } & Primary or lower & $95(19.8)$ & $47(30.3)$ & $<0.001$ & $32(21.8)$ & $19(35.2)$ & 0.004 & $35(15.4)$ & $12(26.1)$ & 0.062 & $28(26.4)$ & $16(29.1)$ & 0.255 \\
\hline & Secondary & $291(60.5)$ & $92(59.4)$ & & $100(68.0)$ & $33(61.1)$ & & $126(55.3)$ & $24(52.2)$ & & $65(61.3)$ & $35(63.6)$ & \\
\hline & Tertiary & $95(19.8)$ & $16(10.3)$ & & $15(10.2)$ & $2(3.7)$ & & $67(29.4)$ & $10(21.7)$ & & $13(12.3)$ & $4(7.3)$ & \\
\hline \multirow[t]{2}{*}{ Employment status } & Employed & $206(42.8)$ & $61(39.4)$ & 0.289 & $47(32.0)$ & $14(25.9)$ & 0.231 & $111(48.7)$ & $20(43.5)$ & 0.429 & $48(45.3)$ & $27(49.1)$ & 0.413 \\
\hline & Unemployed & $275(57.2)$ & $94(60.6)$ & & $100(68.0)$ & $40(74.1)$ & & $117(51.3)$ & $26(56.5)$ & & $58(54.7)$ & $28(50.9)$ & \\
\hline \multirow[t]{3}{*}{ Physical activity } & High & $95(19.8)$ & $26(16.8)$ & 0.045 & $66(44.9)$ & $27(50.0)$ & 0.520 & $81(35.5)$ & $23(50.0)$ & 0.029 & $47(44.3)$ & $25(45.5)$ & 0.957 \\
\hline & Moderate & $192(39.9)$ & $54(34.8)$ & & $52(35.4)$ & $16(29.6)$ & & $102(44.7)$ & $19(41.3)$ & & $38(35.8)$ & $19(34.5)$ & \\
\hline & Low & $194(40.3)$ & $75(48.4)$ & & $29(19.7)$ & $11(20.4)$ & & 45 (19.7) & $4(8.7)$ & & $21(19.8)$ & $11(20.0)$ & \\
\hline \multirow[t]{2}{*}{ Smoking status } & Never smoked & $419(87.1)$ & $138(89.0)$ & 0.386 & $124(84.4)$ & $49(90.7)$ & 0.104 & 205 (89.9) & $43(93.5)$ & 0.369 & $90(84.9)$ & $46(83.6)$ & 0.705 \\
\hline & Past/Current smoker & $62(12.9)$ & $17(11.0)$ & & $23(15.6)$ & $5(9.3)$ & & $23(10.1)$ & $3(6.5)$ & & $16(15.1)$ & $9(16.4)$ & \\
\hline \multirow[t]{2}{*}{ Alcohol consumption } & Never/past consumer & $440(91.5)$ & $139(89.7)$ & 0.330 & $146(99.3)$ & $49(90.7)$ & 0.104 & 205 (89.9) & $43(93.5)$ & 0.369 & $90(84.9)$ & $46(83.6)$ & 0.705 \\
\hline & Current consumer & $41(8.5)$ & $16(10.3)$ & & $1(0.7)$ & $1(1.9)$ & & $23(10.1)$ & $3(6.5)$ & & $16(15.1)$ & $9(16.4)$ & \\
\hline \multirow[t]{2}{*}{ Frequent dining out } & $\leq 3$ times/week & $327(68.0)$ & $110(71.0)$ & 0.333 & $132(89.8)$ & $47(87.0)$ & 0.400 & $110(48.2)$ & $22(47.8)$ & 0.949 & $85(80.2)$ & $41(74.5)$ & 0.130 \\
\hline & > 3 times/week & $154(32.0)$ & $45(29.0)$ & & $15(10.2)$ & $7(13.0)$ & & $118(51.8)$ & $24(52.2)$ & & $21(19.8)$ & $14(25.5)$ & \\
\hline Late dining & $\leq 3$ times/week & $428(89.0)$ & $136(87.7)$ & 0.549 & $129(87.8)$ & $49(90.7)$ & 0.400 & $208(91.2)$ & 41 (89.1) & 0.574 & $91(85.8)$ & $46(83.6)$ & 0.497 \\
\hline
\end{tabular}




\begin{tabular}{|c|c|c|c|c|c|c|c|c|c|c|c|c|c|}
\hline & $>3$ times/week & $53(11.0)$ & $19(12.3)$ & & $18(12.2)$ & $5(9.3)$ & & $20(8.8)$ & $5(10.9)$ & & $15(14.2)$ & $9(16.4)$ & \\
\hline \multirow[t]{2}{*}{ Skipping breakfast } & $\leq 3$ times/week & 364 (75.7) & $119(76.8)$ & 0.699 & $117(79.6)$ & $42(77.8)$ & 0.678 & $175(76.8)$ & $37(80.4)$ & 0.508 & $72(67.9)$ & $40(72.7)$ & 0.271 \\
\hline & $>3$ times/week & $117(24.3)$ & $36(23.2)$ & & $30(20.4)$ & $12(22.2)$ & & $53(23.2)$ & 9 (19.6) & & $34(32.1)$ & $15(27.3)$ & \\
\hline \multirow[t]{2}{*}{ Finishing meals } & Not fast & $229(47.6)$ & $66(42.6)$ & 0.128 & 79 (53.7) & $24(44.4)$ & 0.085 & $121(53.1)$ & $24(52.2)$ & 0.892 & $29(27.4)$ & $18(32.7)$ & 0.198 \\
\hline & Fast & $252(52.4)$ & $89(57.4)$ & & $68(46.3)$ & $30(55.6)$ & & $107(46.9)$ & $22(47.8)$ & & $77(72.6)$ & $37(67.3)$ & \\
\hline
\end{tabular}

${ }^{*}$ - -value ascertained by $\mathrm{X}^{2}$ test 
bioRxiv preprint doi: https://doi.org/10.1101/796144; this version posted October 7,2019 . The copyright holder for this preprint (which was not certified by peer review) is the author/funder, who has granted bioRxiv a license to display the preprint in perpetuity. It is made available under aCC-BY 4.0 International license.

Table 2: Association of sociodemographic and lifestyle factors and diet habits with MetS among the overall population of Johor $(n=481)$

\begin{tabular}{|c|c|c|c|}
\hline \multicolumn{2}{|r|}{ Characteristic } & \multirow{2}{*}{$\begin{array}{c}\text { Crude OR }(95 \% \mathrm{Cl}) \\
1.00\end{array}$} & \multirow[t]{2}{*}{ Adjusted OR $(95 \% \mathrm{Cl})$} \\
\hline Gender & Male & & \\
\hline & Female & $0.90(0.60-1.34)$ & \\
\hline \multirow[t]{4}{*}{ Age (years) } & $<40$ & 1.00 & 1.00 \\
\hline & $40-49$ & $2.42(1.35-4.36)^{*}$ & $2.44(1.27-4.70)^{*}$ \\
\hline & $50-59$ & $1.82(0.99-3.34)$ & $2.80(1.36-5.79)^{*}$ \\
\hline & $\geq 60$ & $2.71(1.50-4.88)^{*}$ & $4.14(1.97-8.69)^{*}$ \\
\hline \multirow[t]{3}{*}{ Ethnicity } & Malay & 1.00 & 1.00 \\
\hline & Chinese & $0.44(0.27-0.69)^{*}$ & $0.37(0.21-0.65)^{*}$ \\
\hline & Indian & $1.86(1.12-3.08)^{*}$ & $1.95(1.12-3.38)^{*}$ \\
\hline \multirow[t]{3}{*}{ Marital status } & Single & 1.00 & 1.00 \\
\hline & Married/living with partner & $1.86(0.97-3.54)$ & $0.81(0.38-1.71)$ \\
\hline & Separated/divorced & $3.48(1.46-8.31)^{*}$ & $0.75(0.26-2.19)$ \\
\hline \multirow[t]{3}{*}{ Education } & Primary or lower & 1.00 & 1.00 \\
\hline & Secondary & $0.47(0.29-0.76)^{*}$ & $0.63(0.37-1.08)$ \\
\hline & Tertiary & $0.21(0.11-0.40)^{*}$ & $0.44(0.20-0.94)^{*}$ \\
\hline \multirow[t]{2}{*}{ Employment status } & Employed & 1.00 & \\
\hline & Unemployed & $1.23(0.84-1.82)$ & \\
\hline \multirow[t]{3}{*}{ Physical activity } & High & 1.00 & 1.00 \\
\hline & Moderate & $1.67(0.98-2.86)$ & $1.14(0.63-2.04)$ \\
\hline & Low & $1.04(0.60-1.80)$ & $1.77(0.99-3.16)$ \\
\hline \multirow[t]{2}{*}{ Smoking status } & Never smoked & 1.00 & \\
\hline & Past/Current smoker & $0.77(0.42-1.39)$ & \\
\hline \multirow[t]{2}{*}{ Alcohol consumption } & Never consumed/past consumer & 1.00 & \\
\hline & Current consumer & $1.39(0.72-2.68)$ & \\
\hline \multirow[t]{2}{*}{ Frequent dining out } & $\leq 3$ times/week & 1.00 & \\
\hline & > 3 times/week & $0.81(0.54-1.24)$ & \\
\hline \multirow[t]{2}{*}{ Late dining } & $\leq 3$ times/week & 1.00 & \\
\hline & > 3 times/week & $1.20(0.66-2.18)$ & \\
\hline \multirow[t]{2}{*}{ Skipping breakfast } & $\leq 3$ times/week & 1.00 & \\
\hline & > 3 times/week & $0.92(0.58-1.43)$ & \\
\hline \multirow[t]{2}{*}{ Finishing meals } & Not fast & 1.00 & 1.00 \\
\hline & Fast & $1.35(0.92-1.98)$ & $1.15(0.75-1.78)$ \\
\hline
\end{tabular}

*P-value $<0.05$

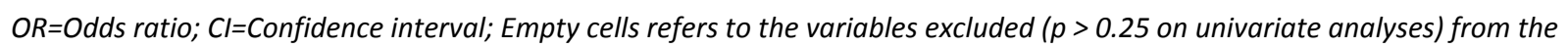
model 
Table 3: Association of sociodemographic and lifestyle factors and diet habits with MetS among the three major ethnicities of Johor

\begin{tabular}{|c|c|c|c|c|c|c|c|}
\hline & & \multicolumn{2}{|c|}{ Malay (n=147) } & \multicolumn{2}{|c|}{ Chinese $(n=228)$} & \multicolumn{2}{|c|}{ Indian $(n=106)$} \\
\hline \multicolumn{2}{|c|}{ Characteristic } & Crude OR (95\% Cl) & Adjusted OR (95\% Cl) & Crude OR $(95 \% \mathrm{CI})$ & Adjusted OR (95\% Cl) & Crude OR (95\% Cl) & Adjusted OR $(95 \% \mathrm{Cl})$ \\
\hline \multirow[t]{2}{*}{ Gender } & Male & 1.00 & 1.00 & 1.00 & & 1.00 & 1.00 \\
\hline & Female & $1.67(0.77-3.62)$ & $1.16(0.35-2.85)$ & $0.78(0.40-1.49)$ & & $0.45(0.20-1.02)$ & $0.62(0.22-1.80)$ \\
\hline \multirow[t]{4}{*}{ Age (years) } & $<40$ & 1.00 & & 1.00 & 1.00 & 1.00 & 1.00 \\
\hline & $40-49$ & $1.03(0.42-2.49)$ & & $3.08(0.73-13.00)$ & $3.08(0.69-13.62)$ & $5.91(2.06-16.99)^{*}$ & $8.24(2.38-28.59)^{*}$ \\
\hline & $50-59$ & $1.69(0.63-4.48)$ & & $2.26(0.59-8.64)$ & $2.43(0.60-9.86)$ & $14.14(3.08-64.88)^{*}$ & $25.25(4.64-137.57)^{*}$ \\
\hline & $\geq 60$ & $1.97(0.66-5.89)$ & & $5.41(1.52-19.20)^{*}$ & $5.43(1.39-21.13)^{*}$ & $9.00(2.54-31.96)^{*}$ & $14.25(3.22-63.84)^{*}$ \\
\hline \multirow[t]{3}{*}{ Marital status } & Single & 1.00 & 1.00 & 1.00 & & 1.00 & \\
\hline & Married/living with partner & $0.32(0.05-2.00)$ & $0.16(0.02-1.27)$ & $1.75(0.73-4.22)$ & & $2.20(0.52-9.38)$ & \\
\hline & Separated/divorced & $1.11(0.14-8.68)$ & $0.33(0.03-3.63)$ & $0.60(0.07-5.45)$ & & $3.20(0.54-18.98)$ & \\
\hline \multirow[t]{3}{*}{ Education } & Primary or lower & 1.00 & 1.00 & 1.00 & 1.00 & 1.00 & \\
\hline & Secondary & $0.34(0.15-0.77)^{*}$ & $0.38(0.15-0.95)^{*}$ & $0.45(0.20-1.03)$ & $0.64(0.26-1.58)$ & $0.88(0.36-2.14)$ & \\
\hline & Tertiary & $0.10(0.02-0.55)^{*}$ & $0.08(0.01-0.58)^{*}$ & $0.34(0.13-0.87)^{*}$ & $0.54(0.19-1.57)$ & $0.33(0.08-1.35)$ & \\
\hline \multirow[t]{2}{*}{ Employment status } & Employed & 1.00 & 1.00 & 1.00 & & 1.00 & \\
\hline & Unemployed & $1.57(0.75-3.30)$ & $0.78(0.30-2.09)$ & $1.30(0.68-2.49)$ & & $0.73(0.34-1.56)$ & \\
\hline \multirow[t]{3}{*}{ Physical activity } & High & 1.00 & & 1.00 & 1.00 & 1.00 & \\
\hline & Moderate & $0.73(0.28-1.89)$ & & 2.35 (0.75-7.35) & $2.30(0.72-7.34)$ & $0.91(0.31-2.64)$ & \\
\hline & Low & $1.13(0.46-2.78)$ & & $4.06(1.31-12.64)^{*}$ & $4.76(1.49-15.26)^{*}$ & $1.03(0.37-2.89)$ & \\
\hline \multirow[t]{2}{*}{ Smoking status } & Never smoked & 1.00 & 1.00 & 1.00 & & 1.00 & \\
\hline & Past/Current smoker & $0.42(0.15-1.22)$ & $0.60(0.15-2.42)$ & $0.56(0.16-1.99)$ & & $1.23(0.42-3.58)$ & \\
\hline \multirow[t]{2}{*}{ Alcohol consumption } & Never/past consumer & 1.00 & & 1.00 & & 1.00 & \\
\hline & Current consumer & - & & $0.99(0.38-2.58)$ & & $9.78(1.19-80.24)^{*}$ & \\
\hline \multirow[t]{2}{*}{ Frequent dining out } & $\leq 3$ times/week & 1.00 & & 1.00 & & 1.00 & 1.00 \\
\hline & $>3$ times/week & $1.58(0.54-4.64)$ & & $1.02(0.54-1.95)$ & & $2.15(0.79-5.85)$ & $4.18(0.98-17.83)$ \\
\hline \multirow[t]{2}{*}{ Late dining } & $\leq 3$ times/week & 1.00 & & 1.00 & & 1.00 & \\
\hline & $>3$ times/week & $0.63(0.21-1.87)$ & & $1.36(0.47-3.95)$ & & $1.47(0.48-4.46)$ & \\
\hline \multirow[t]{2}{*}{ Skipping breakfast } & $\leq 3$ times/week & 1.00 & & 1.00 & & 1.00 & \\
\hline & $>3$ times/week & $1.19(0.52-2.71)$ & & $0.76(0.34-1.70)$ & & $0.63(0.28-1.44)$ & \\
\hline \multirow[t]{2}{*}{ Finishing meals } & Not fast & 1.00 & 1.00 & 1.00 & & 1.00 & 1.00 \\
\hline & Fast & $1.81(0.92-3.56)$ & $2.17(1.02-4.60)^{*}$ & $1.05(0.55-1.99)$ & & $0.56(0.24-1.35)$ & $0.68(0.25-1.81)$ \\
\hline
\end{tabular}

*P-value $<0.05$

$O R=$ Odds ratio; $C l=$ Confidence interval; Empty cells refers to the variables excluded ( $p>0.25$ on univariate analyses) from the model 
bioRxiv preprint doi: https://doi.org/10.1101/796144; this version posted October 7, 2019. The copyright holder for this preprint (which was not certified by peer review) is the author/funder, who has granted bioRxiv a license to display the preprint in perpetuity. It is made available under aCC-BY 4.0 International license. 


\section{Figures}

Fig 1: Proportions of MetS and its components, overall and among the three major ethnic groups in Johor

$$
\mathbb{Z} \text { Total }(n=481) \quad \boldsymbol{a} \text { Malay }(n=147) \quad \boldsymbol{\Phi} \text { Chinese }(n=228) \quad \boldsymbol{\square} \text { Indian }(\mathrm{n}=106)
$$

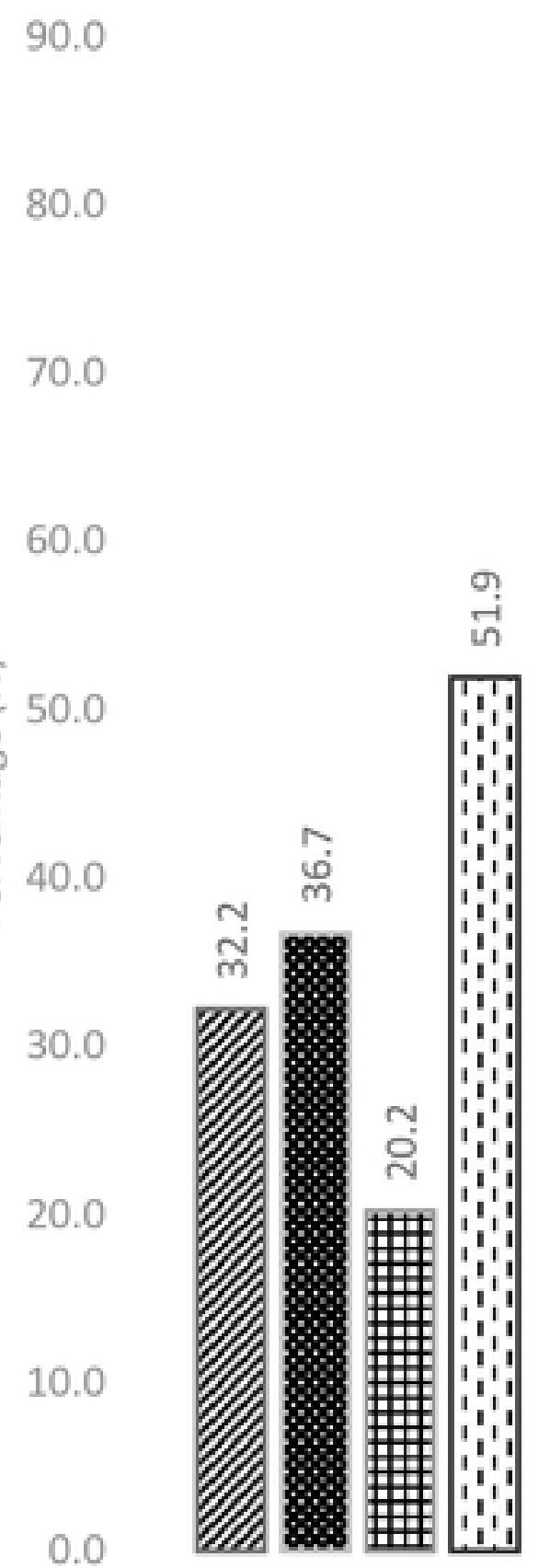

Metabolic Syndrome

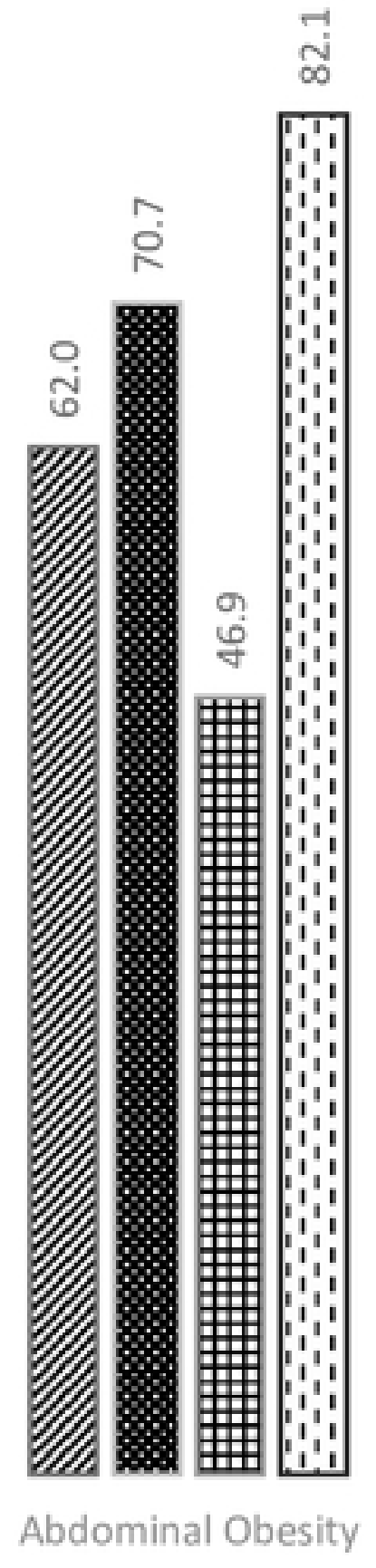

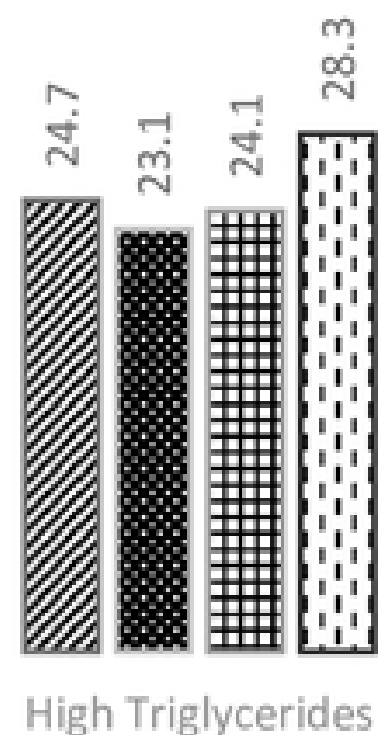

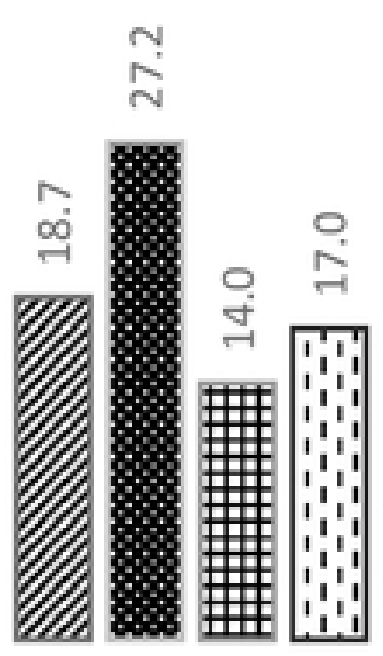

High Blood Glucose

\section{Figure}

